\title{
An Efficiency-Wage Theory of the Weather
}

\section{Citation}

Barro, Robert J. 1989. An efficiency-wage theory of the weather. Journal of Political Economy 97(4): 999-1001.

\section{Published Version}

doi:10.1086/261640

\section{Permanent link}

http://nrs.harvard.edu/urn-3:HUL.InstRepos:3451295

\section{Terms of Use}

This article was downloaded from Harvard University's DASH repository, and is made available under the terms and conditions applicable to Other Posted Material, as set forth at http:// nrs.harvard.edu/urn-3:HUL.InstRepos:dash.current.terms-of-use\#LAA

\section{Share Your Story}

The Harvard community has made this article openly available.

Please share how this access benefits you. Submit a story.

Accessibility 


\section{Miscellany}

\section{An Efficiency-Wage Theory of the Weather}

Many people have noticed that it's getting too hot lately. But most suggested remedies have been micro oriented and have neglected the role of macro policies. To see how these policies would work, I construct a simple macroeconomic theory based on efficiency wages. ${ }^{1}$ This choice of framework is natural because the efficiency-wage model has already been successful in analyzing unemployment, which is another social problem. The adaptation of the model to the weather suggests that many other applications would also be fruitful.

The key observation is that workers' supply of effort depends on their wage, relative to that available elsewhere, and on the temperature. If firm $i$ employs $N_{i}$ workers, the effective supply of labor input can be written as

$$
L_{i}=N_{i} \cdot f\left(w_{i}-\bar{w}, T\right),
$$

where $w_{i}$ is the firm's wage rate, $\bar{w}$ is the wage paid by other firms, and $T$ is the temperature (measured in degrees Kelvin). Effort is increasing in $w_{i}-\bar{w}$ and in $T$. (It used to be thought that people worked harder when it got colder, but that view was refuted by Carnot [1846] in his famous rat experiments. $)^{2}$ Also, as $T$ rises, the marginal effect of $w_{i}-\bar{w}$ on effort diminishes; that is, if it gets really hot, people work a lot and pay little attention to the wage.

Each firm chooses $w_{i}$, given $\bar{w}$ and $T$, to maximize profits or, equivalently, to minimize the costs of providing a given amount of effective

I have benefited from discussions of this research with Jason Barro.

${ }^{1}$ For a related analysis based on the reserve army theory, see Marx (1885).

${ }^{2}$ Carnot is not a misspelling of Cournot, but is instead the name of the French engineer who discovered the second law of thermodynamics. Carnot found that rats moved around more and more briskly as he turned up the heat, although his apparatus allowed a maximum temperature of only $312^{\circ} \mathrm{K}$. As he reduced the temperature, the rats became more and more lazy and stopped moving entirely at $230^{\circ}$. Carnot was also the first to discover a form of hysteresis in animal behavior. If he reduced the temperature to $230^{\circ}$, the rats failed to move even if he restored the temperature to $312^{\circ}$. 
labor input. Consequently, as is familiar from the efficiency-wage literature, the optimizing firm operates where the elasticity of effort with respect to $w_{i}$ is unity. This condition implies that the firm sets $w_{i}-\bar{w}$ as a decreasing function of $T$ :

$$
w_{i}-\bar{w}=h(T), \quad h^{\prime}<0 .
$$

I assume that $w_{i}>\bar{w}$ if $T=0$ (which requires some additional weak conditions about the function $f(\cdot)$ in eq. [1]).

Suppose that all firms and workers are identical, so that $w_{i}=\bar{w}$ holds in equilibrium. Then the equilibrium temperature, denoted by $T^{*}$, is determined by

$$
h\left(T^{*}\right)=0 .
$$

Given the properties of the function $h(\cdot)$, which follow from those of $f(\cdot)$ in equation (1), equation (3) has two immediate implications. First, the temperature is positive in equilibrium, $T^{*}>0$, and second, the temperature exceeds the Pareto-optimal value. That is, it is too hot on average. Some simple extensions would make the model consistent with two other empirical observations: namely, it is typically hotter during the day than at night, and the temperature follows a regular seasonal pattern. However, further research is needed to understand the absence of a systematic pattern in the temperature during weekends and holidays. ${ }^{3}$

In a secular context, rising real income tends to induce shirking if leisure is a normal good. A steadily rising temperature (the "greenhouse effect") motivates workers to stay diligent. Therefore, instead of being a cause of concern, this effect is an example of the efficient working of the market.

The role for policy comes from the government's ability to shift the effort function, $f(\cdot)$, in equation (1) and thereby affect the equilibrium temperature, $T^{*}$. The government has a variety of instruments that would induce people to expend more effort on the job. For example, it is well known that budget deficits encourage hard work (see Ricardo 1821). Therefore, an expansionary fiscal policy would cool things off. This result can explain why Latin countries tend to have large budget deficits and high average temperatures. Similarly, the model can explain why Scandinavian countries tend to have high marginal tax rates and low average temperatures.

\footnotetext{
${ }^{3}$ One hint on how to proceed is that weekends did not apply in ancient Rome. Friedman (1987) discussed the determination of indoor temperature. The weakness of his otherwise elegant theory is the treatment of outdoor temperature as exogenous. For example, he left unexplained the observation that average winter temperatures in Los Angeles are higher than those in Chicago. (Such gaps in economic analysis amount to an open invitation to sociologists.) The present theory can readily explain the patterns in the weather across cities or regions.
} 
Some economists will probably think that the efficiency-wage model is a bizarre theory of the weather. But experts in the efficiency-wage area will already have recognized that the analysis of the weather parallels the usual treatment of unemployment. In fact, substitution of $U$ for $T$ yields the standard efficiency-wage model of unemployment. It seems reasonable to conclude that the approach is just as valuable for analyzing the weather as it is for understanding unemployment. $^{4}$

\section{Harvard University}

ROBERT J. BARRO

\section{References}

$\rightarrow$ Carmichael, Lorne. "Can Unemployment Be Involuntary? Comment." A.E.R. 75 (December 1985): 1213-14.

Carnot, Sadi. "Efficiency Wages versus Temperature in the Labor Supply of Rats." J. Royal Soc. 11 (November 1846): 12-27.

$\rightarrow$ Friedman, David. "Cold Houses in Warm Climates and Vice Versa: A Paradox of Rational Heating." J.P.E. 95 (October 1987): 1089-97.

Marx, Karl. "Das Effizienz-Lohn Modell entspricht meiner Theorie der Reserve-Armee aus Arbeitslosen." Zeitschrift Deutscher Ökonomie 26 (Frühjahr 1885): 1-215.

Ricardo, David. The Ricardian Theorem with Adaptive Expectations and Variable Labor Supply. Pamphlet no. 11. London: Macmillan, 1821.

\footnotetext{
${ }^{4}$ Carmichael (1985) argued that the efficiency-wage model was a bizarre theory of unemployment because involuntarily unemployed persons would offer some kind of payment for jobs that they would like to have. Then these payments-rather than unemployment-would adjust to generate an equilibrium. This point is somewhat disturbing since it seems also to invalidate my positive analysis of the weather.
} 